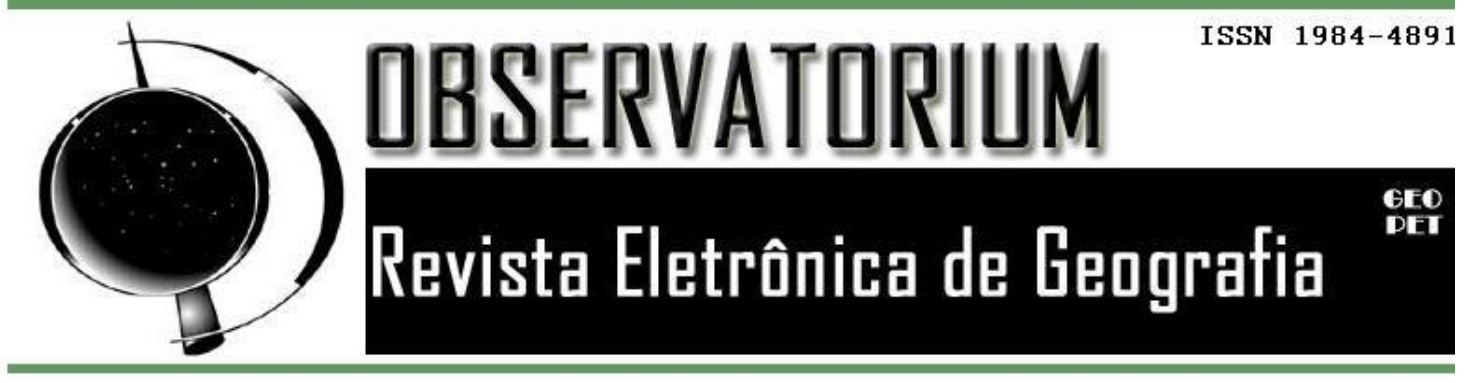

\title{
Estágio Supervisionado na graduação em Geografia: um relato de experiência na educação infantil e nos anos iniciais do ensino fundamental
}

Supervised internship in undergraduate education in Geography: an experience report in early childhood education and in the early years of elementary school

\section{Vítor Oliveira Gregolate}

Discente do Curso de Graduação em Geografia do Instituo de Geografia da Universidade Federal de Uberlândia. Bolsista PET MEC.

E-mail: vitorgregolate@hotmail.com

\section{Resumo:}

O presente trabalho objetiva narrar as experiências escolares na educação infantil e nos anos iniciais ocorridas a partir das atividades desenvolvidas no Estágio Supervisionado I, no primeiro semestre do ano de 2018, como disciplina obrigatória do curso de licenciatura em Geografia do Instituto de Geografia da Universidade Federal de Uberlândia.

Palavras-Chave: Educação. Ensino de Geografia. Formação docente.

\begin{abstract}
:
The present work aims to narrate the school experiences in early childhood education and in the first school years. The work has as its centrality the activities developed in Supervised Internship I, in the first semester of 2018, as a mandatory subject of the Geography graduation course at the Instituto de Geografia da Universidade Federal de Uberlândia
\end{abstract}

Keywords: Education. Geography teaching. teacher training 


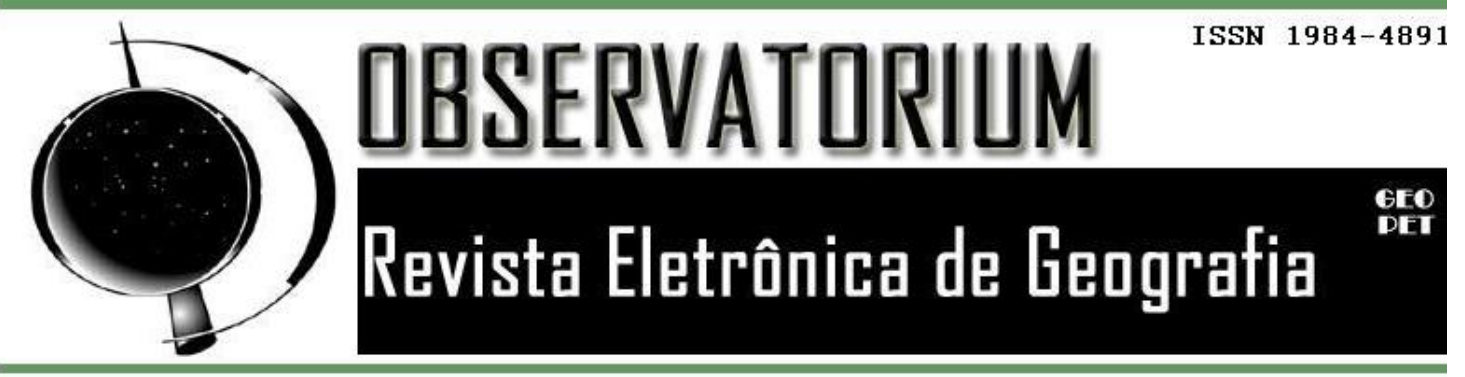

Introdução

O Estágio Supervisionado em Geografia tem como objetivo ser o primeiro contato do discente do curso de licenciatura com uma escola do Ensino Básico, objetivando a habilitação em licenciatura para ministrar aulas. É um passo importante para a formação docente que almeja a profissão.

A disciplina Estágio Supervisionado I é ofertada no $5^{\circ}$ período da Universidade Federal de Uberlândia, no curso do Geografia, com carga horaria de 6oh, divididas em 45 horas de teorias e 15 horas de práticas, no qual o discente, de acordo com a ementa da disciplina:

Discutir e desenvolver estratégias que possibilitem aos alunos a compreensão da relação entre teoria e prática existente no espaço escolar, considerando o método geográfico (Observação, descrição, extensão, explicação, analogia, síntese e representação) e sua aplicação nas aulas de Geografia nessa fase da educação, com vistas a proporcionar a formação de um profissional reflexivo, dinâmico e autônomo.

O Estágio Supervisionado I tem a proposta de observação da sala de aula e de atividades realizadas nela, abrangendo o período do Ensino Fundamental I ( $1^{\mathrm{a}}$ a $5^{\mathrm{o}}$ ano) contribuindo para o ensinamento na formação do profissional, proporcionando um contato maior com sua área de atuação. Apesar do período do Ensino Fundamental I ser, geralmente, ministrado por professores polivalentes, é importante a observação do professor de Geografia para compreender, mesmo que minimamente, a trajetória dos alunos que ele receberá quando ministrar aulas para o $6^{\circ}$ ano. Além de proporcionar as questões teóricometodológicas das principais correntes didáticas que envolvem o ensino não só de Geografia, mas que envolvem também o desenvolvimento dos alunos como cidadãos plenos.

Nesse sentido, o presente trabalho se refere as atividades desenvolvidas no Estágio Supervisionado I, ocorrido no primeiro semestre do ano de 2018 sob a orientação do professor Dr. Vicente de Paulo da Silva do Instituto de Geografia da Universidade Federal de Uberlândia. 


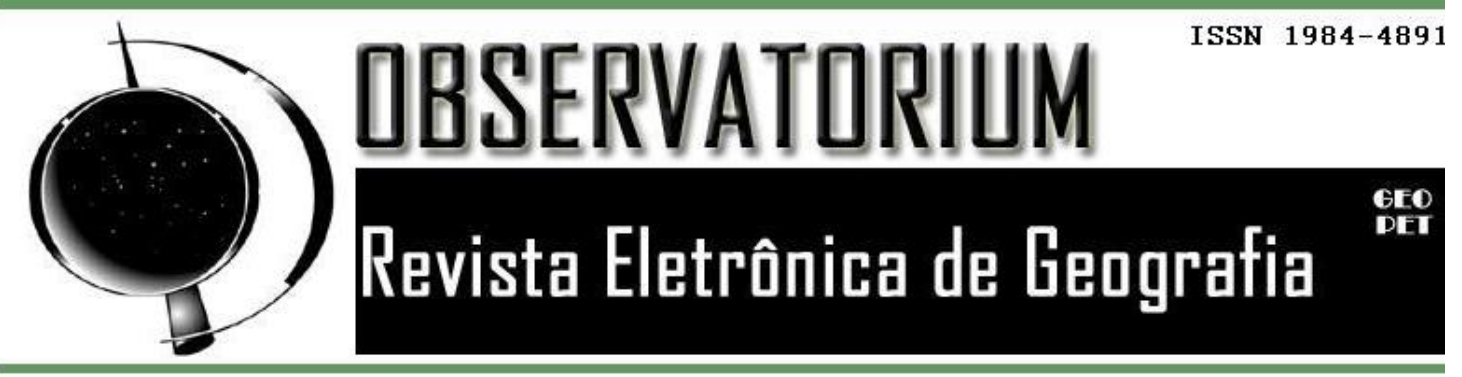

Visita ao Ensino Infantil

A pedido do professor Vicente, os alunos do Estagio Supervisionado I deveriam visitar uma escola de ensino infantil para visualizar os alunos e compreender melhor o desenvolvimento dos mesmos antes de ingressarem no Ensino Fundamental. Como o Centro Pedagógico Metta oferece essa modalidade de ensino, essa atividade foi realizada lá.

Acompanhei as crianças do Ensino Infantil, assim como as atividades realizadas por eles. O professor Vicente nos orientou para que fossem analisadas as cantigas que fazem parte da educação infantil, assim como as atividades realizadas por eles.

Ao chegar na escola, a professora levou os alunos ao pátio, onde ela cantou com eles algumas canções clássicas como as que eu identifiquei como "Ciranda Cirandinha", "Dona Aranha", "Borboletinha”, "O Cravo e a Rosa”, além de algumas outras que acredito serem mais recentes e que eu não conheço.

Ao retornar para a sala, a professora entregou os livros de desenho para os alunos, e realizou uma atividade do livro didático, que envolvia recorte e colagem de figuras geométricas para a formação de desenhos como coelhos e gatos.

Além disso, a professora também entregou algumas folhas e pediu para os alunos desenharem a forma com que eles enxergam a escola. Essa atividade achei muito interessante, por dialogar com o ensino de Geografia para crianças, que envolve a descrição do espaço vivido. Percebi também a diferença entre o desenvolvimento de algumas das crianças em relação a essa percepção, algumas possuíam um domínio maior sobre a coordenação motora fina do que outras. A professora também pediu para os alunos escrevessem os seus nomes atrás da folha, sendo algumas crianças já possuíam o domínio sobre a letra cursiva, e algumas ainda escreviam com a letra de forma.

Um dos alunos, quando me entregou uma das folhas, assinou seu nome com as letras escritas de forma espelhada, quando indaguei a professora sobre isso, ela me explicou que ele havia chegado à escola a apenas 3 semanas, e que aparentemente ele nunca havia frequentado nenhuma outra. 

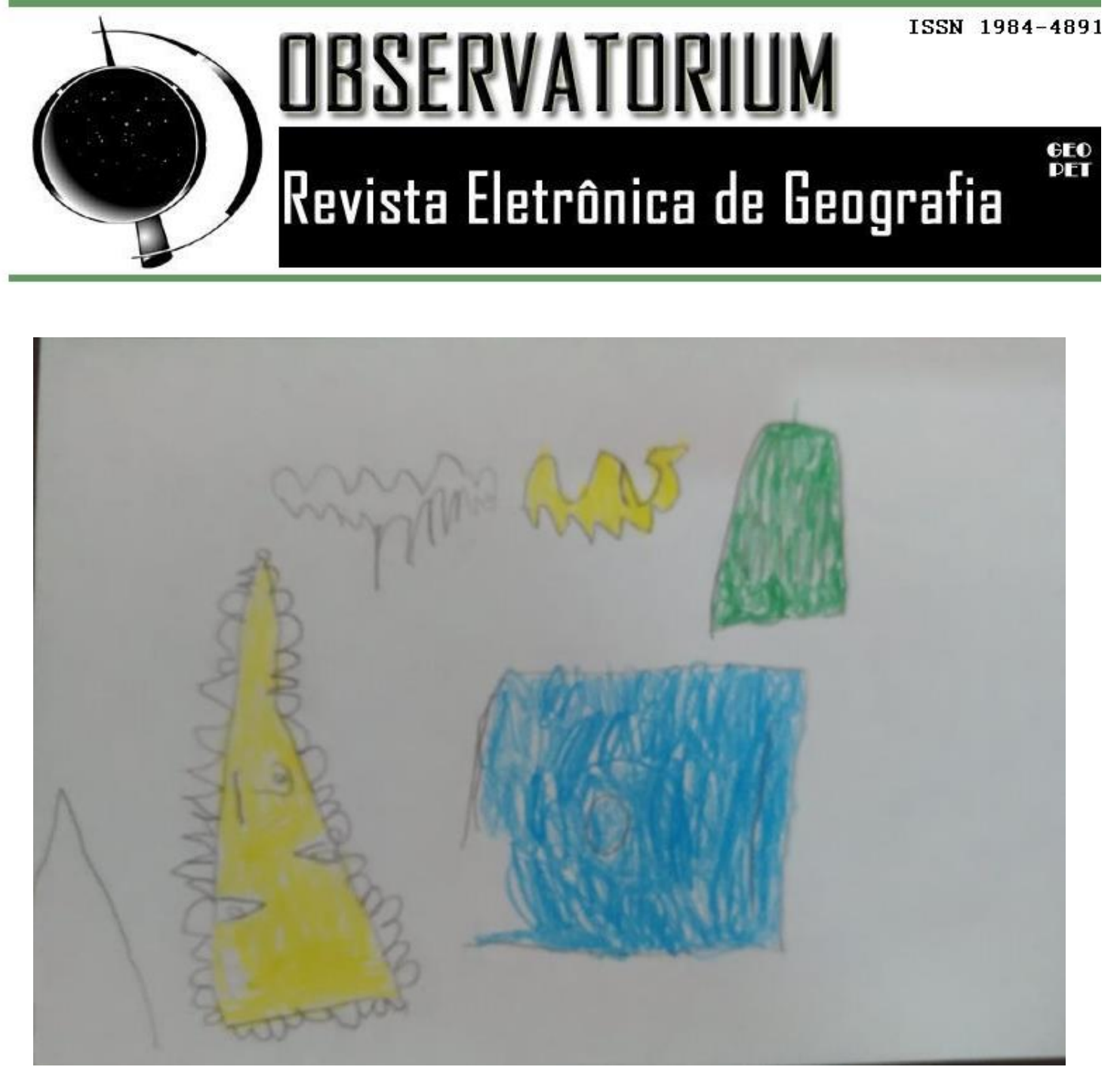

Imagem 1. Fonte: Aluno do Ensino Infantil

No desenho acima, ao perguntar o que estava desenhado, o aluno respondeu que, o quadrado em verde é uma área da escola que contém uma roda de conversa com assentos de madeira, o desenho em azul é a quadra, e o triangulo amarelo o corredor; os desenhos na parte de cima, são as cabras que vivem na escola. Ao perguntar porque ele desenhou essas partes ele respondeu que eram as coisas favoritas dele na escola.

Essa atividade, por fim, foi socializada em sala de aula com os alunos do Estágio. 


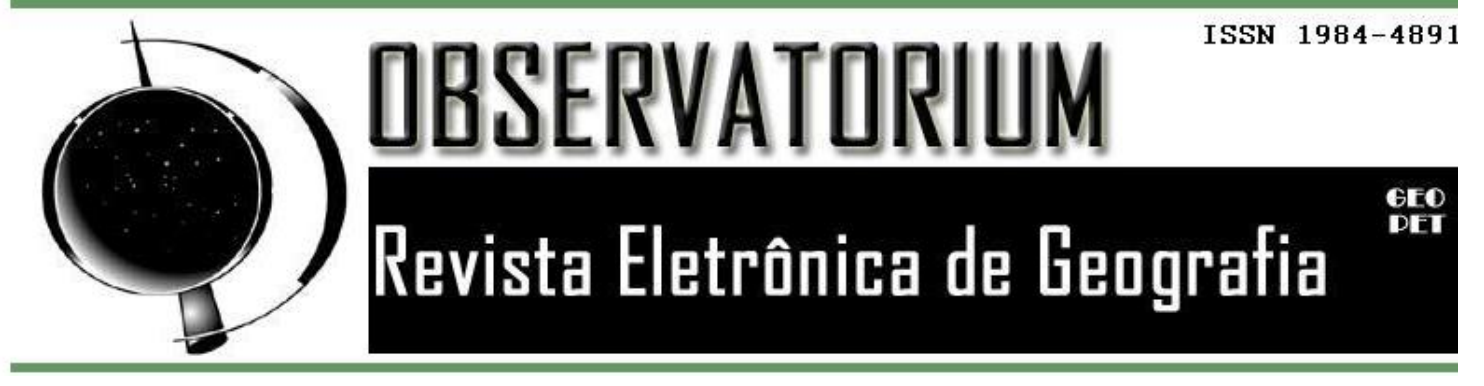

Histórico da escola.

O Centro Pedagógico Metta é uma escola recente, sendo fundada a apenas dois anos atrás em 2016. A Diretora da escola, a Iara, anteriormente diretora do Centro Educacional São Pascoal, que por questões ocorridas dentro dessa escola decidiu abrir sua própria escola. Primeiramente ela abriu o Centro de Reforço Metta, mas, devido a demanda por uma escola que contemplasse o ensino básico completo, ela, junto com seus filhos, decidiu abrir o Centro Pedagógico Metta.

A escola em si comporta alunos desde o Ensino Infantil até o $7^{\circ}$ ano do Ensino Fundamental, mas a diretora Iara de Carvalho Silva disse que há planos para aumentar o espaço físico para atender alunos até o $9^{\circ}$ ano.

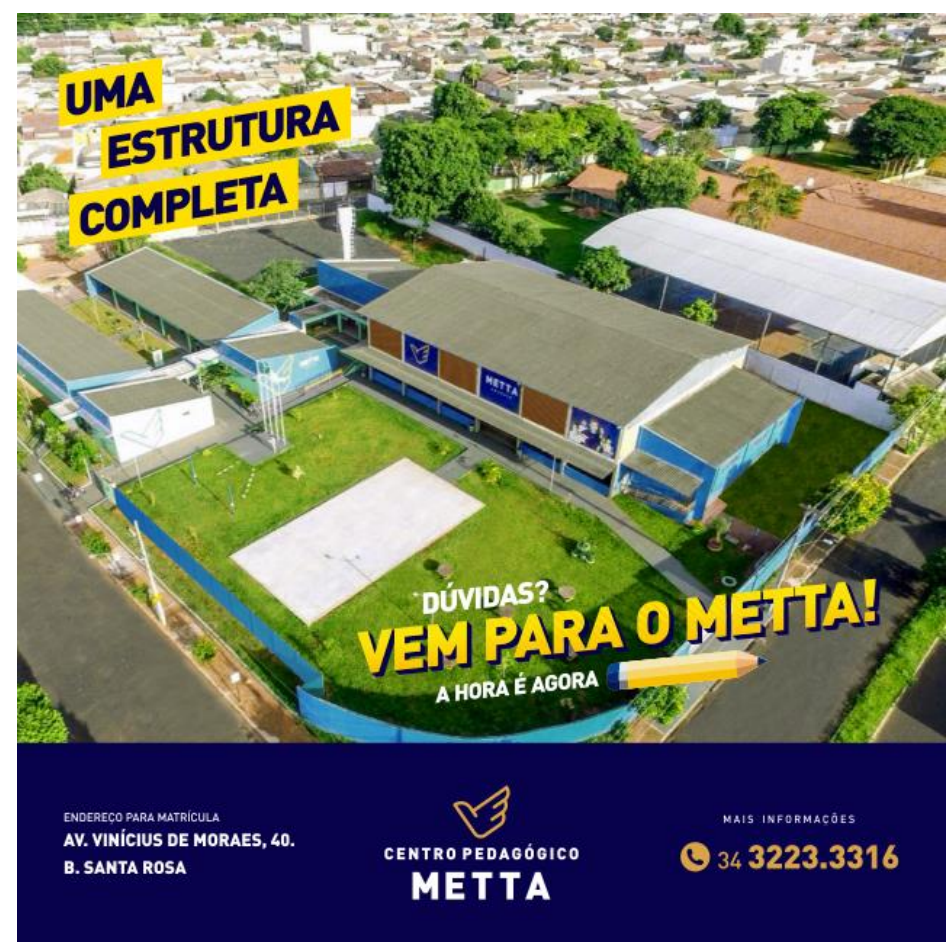

Imagem 2: Panfleto da escola. Fonte: https://goo.gl/fkKNvW

Apesar de ser uma escola particular, a diretora disse que tem interesse em abrir vagas para atender alunos de baixa renda, mas que, devido a questões financeiras, não há possibilidade de isso ser realizado no momento. 

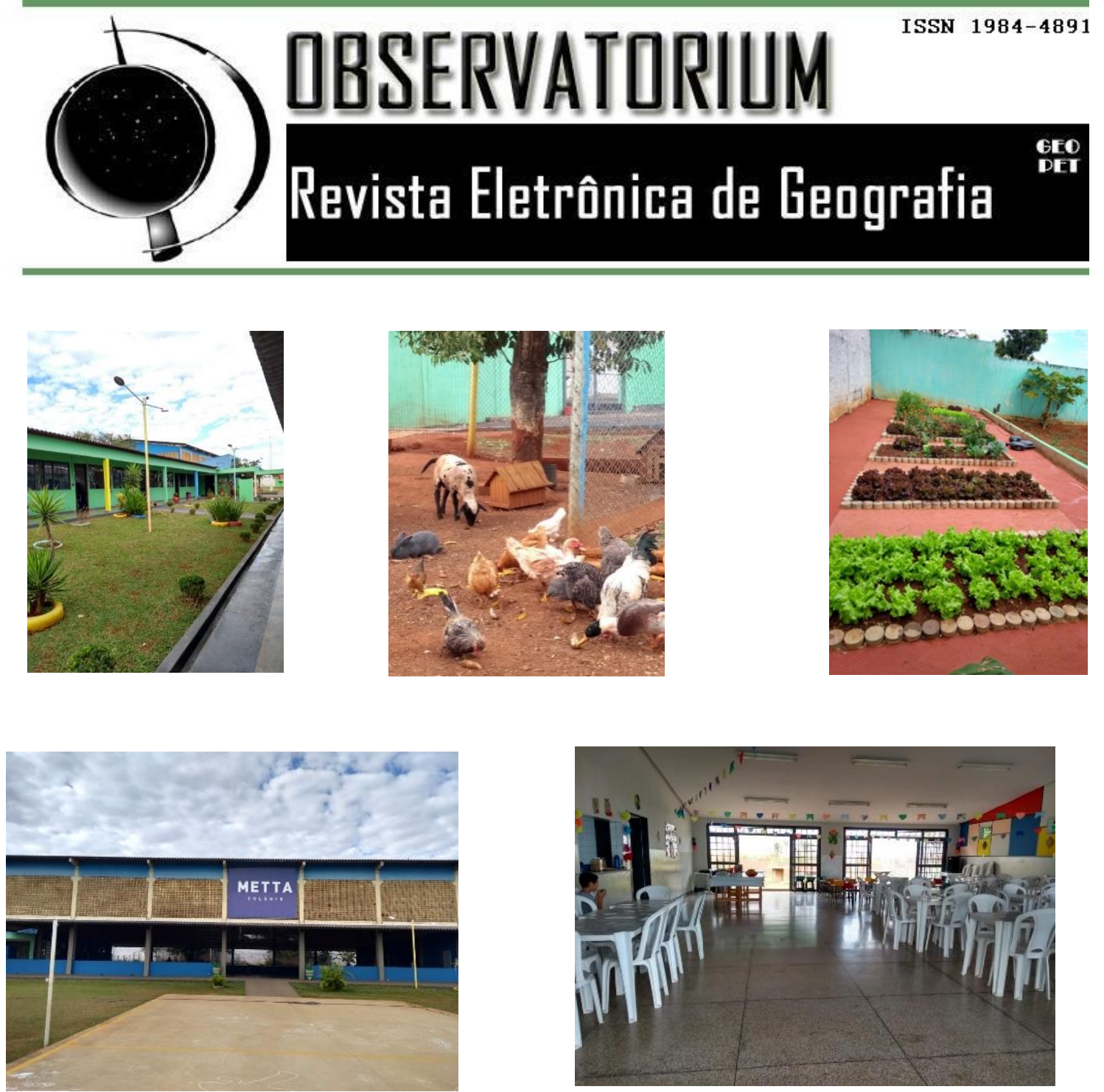

Imagens 03 - Fotos da escola. Fonte: autor.

\section{Atividades práticas realizadas na escola.}

Durante a visita a escola, observei um espaço muito bem decorado e limpo, com pinturas e acabamentos muito bem feitos, em todas as paredes havia alguma forma de decoração. Logo após passar pela recepção da escola, já se encontram as salas de aula, sendo separadas, o Ensino Infantil e Ensino Fundamental, com turmas da $1^{\circ}$ a $7^{\circ}$ ano, por um jardim interno. Ao fundo da escola se localiza o refeitório e a quadra, além de uma horta, cuidada pelos próprios alunos, com a ajuda dos pais e dos professores; e um lugar destinado aos animais, contendo duas cabras, coelhos e galinhas. A diretora da escola explicou a importância das áreas verdes, pois disse que a maioria dos alunos nunca tinham visto um pé de acerola, e não faziam ideia de como ele realmente nascia; além de também dizer que, uma das cabras havia parido recentemente, e que o 


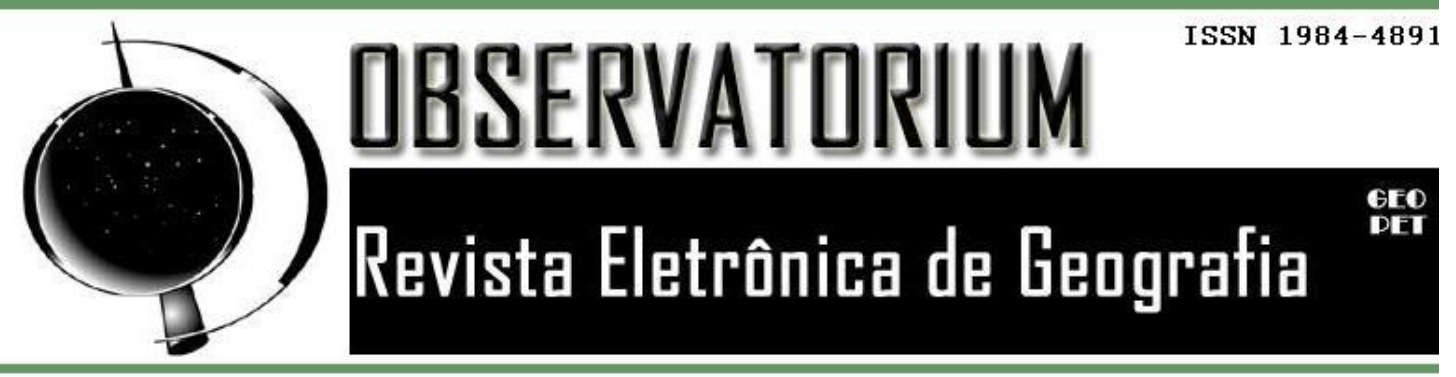

acontecimento foi “o maior evento da escola até então”, já que os alunos ficaram maravilhados.

Em geral, a escola é muito agradável, com muita vegetação, tornando o ambiente fresco e muito bem iluminado. Reparei também a falta de infraestrutura de acessibilidade, tanto pela portaria principal, que possui escadas, quanto da entrada do estacionamento, feito com brita, apesar de os banheiros possuírem divisórias especificas para cadeirantes.

As salas de aula são pequenas, decoradas e possuem poucos alunos por turma, as mesas são coloridas e as aulas são ministradas em quadro branco. É interessante de se reparar, que os banheiros, e principalmente as carteiras do Ensino Infantil são miniaturizadas para facilitar o uso dos alunos mais novos.

\section{Observação e análise do entorno onde se localiza a escola.}

A escola está localizada na Rua Vinícius de Morais número 40 no Bairro Santa Rosa no município mineiro de Uberlândia, próximo a escola prevalece residências com poucos comércios. Localizada atrás da escola outra escola chamada Escola Estadual Angelino Pavan e em uma rua que cruza a Rua Vinicius de Morais há uma escola municipal chamada Escola Municipal de Ensino Infantil Professor Sergio Aparecido da Silva.

A entrada frontal do Centro Pedagógico Metta é bem arborizada, sendo que a instalação ocupa aproximadamente um quarteirão ao todo. Logo ao portão, do outro lado da rua, existe um pequeno mercadinho que vende produtos alimentícios básicos, como pão, leite, doces, bebidas, etc.

Há também um ponto de ônibus logo a esquina com a escola, apesar de eu não saber quantos alunos utilizam o transporte público para chegar a escola, ouvi de sobressaio um professor perguntando a um deles se ele tinha vindo de ônibus no dia em questão.

Em geral, no entorno, não há casas que aparentem ser de alto padrão, sendo a maioria de arquitetura bem simples e germinada. 


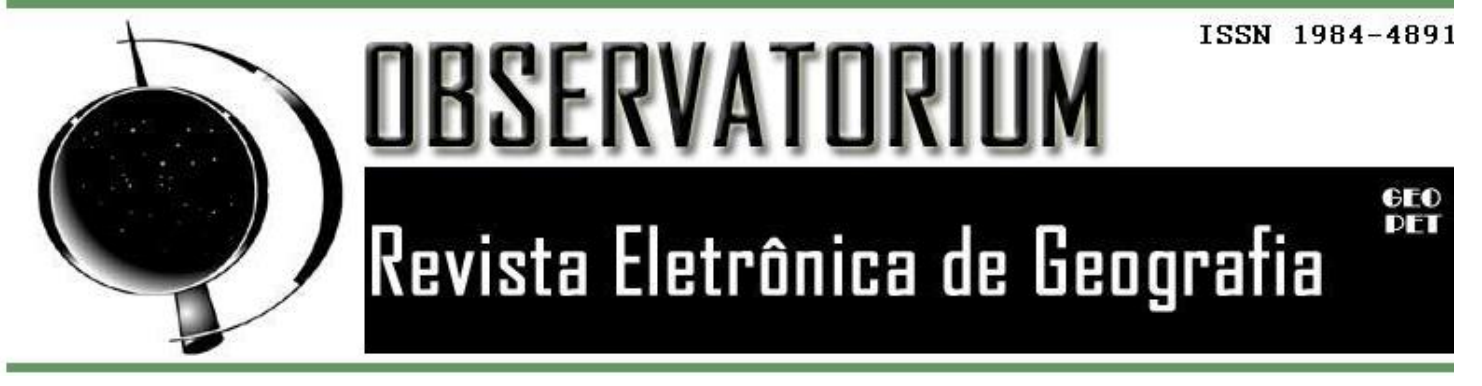

Analise da biblioteca.

A biblioteca da escola está localiza entre a recepção e a secretaria da escola. Não é uma sala muito grande, deduzo que deve possuir aproximadamente 20m²; equipada com televisor, cadeiras, impressoras (curiosamente nenhum computador visível).

Os livros ficam dispostos nas paredes da sala, sendo que a maioria são livros didáticos de diversas editoras e para diversos anos, desde o Ensino Infantil até o Ensino Médio (apesar da escola não possuir essa modalidade de ensino), em uma estante estão localizadas enciclopédias e outros livros clássicos da literatura moderna brasileira. Em uma estante trancada estão localizados livros de apoio didático para auxiliar os professores.

Há também uma salinha, bem mal iluminada, ao fundo, que possui livros de contos infantis e gibis.

\section{Observação do intervalo.}

No intervalo os alunos ficam livres para andar pelas instalações da escola, sendo que a maioria prefere ficar no pátio aberto ou na quadra. Os horários são divididos entre os alunos do ensino infantil e os alunos do ensino fundamental, sendo que os primeiros realizam o intervalo entre as 9 horas e 20 minutos da manhã, e os segundos as 9 horas e quarenta minutos da manhã. Aparentemente, a maioria dos alunos, principalmente os do fundamental, trazem seus lanches de suas casas, e comem fora do refeitório, sendo que o mesmo oferece frutas, biscoitos e suco para os alunos se alimentarem.

A escola possui uma política interessante de sustentabilidade, pedindo que os alunos tragam seus lanches sem embalagem plástica, evitando assim o acumulo de lixo na escola, além de não permitir o consumo de refrigerante dentro das instalações. Não sei dizer o quão efetivo é essa política, pois, mesmo não trazendo as embalagens plásticas para a escola, elas continuam existindo em outro lugar. 


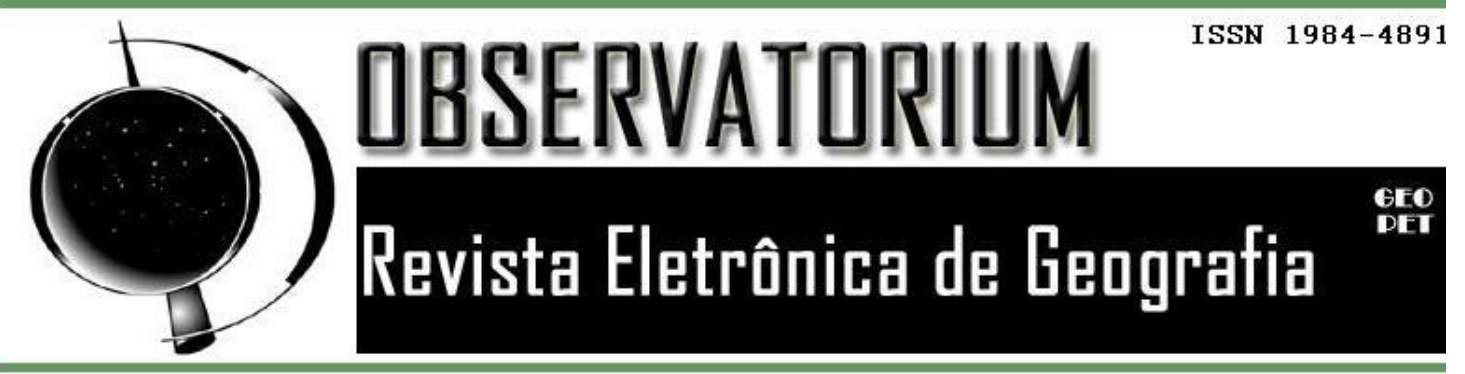

Em geral os alunos ficam interagindo entre si, correndo de um lado para o outro no pátio e na quadra; os professores deixam alguns brinquedos como cordas de pular, bambolês, os quais os alunos usam para brincar.

\section{Oficina da Copa do Mundo.}

Nessa atividade realizada no dia 29 de junho de 2018, foi feita uma breve introdução sobre as condições físicas, populacionais, econômicas e a localização da Rússia, sede da Copa Mundial de Futebol. Os alunos, em especifico os meninos, tiveram grande interesse em saber mais sobre o país, além de demonstrarem conhecimento sobre algumas curiosidades da Rússia, como ela ser o maior país do mundo em extensão territorial, o clima muito frio no norte do país e estar localizada entre dois continentes.

Após a explicação, foi utilizado uma placa metálica que contém um mapa das divisões políticas do mundo, que, através da impressão das bandeiras dos países que participaram da copa, tinha como objetivos que os alunos identifiquem as bandeiras e sua localização no mapa. Mais uma vez fui surpreendido por eles conhecerem as bandeiras e facilmente localizarem os países no mapa. A maior dificuldade encontrada por eles foram identificar no mapa a localização alguns países, como a Islândia, na Europa; e o Senegal, Marrocos e Tunísia na África.

\section{Aula sobre a População de Uberlândia.}

Ao conversar com a professora (Rosilene) que ministra as aulas de Geografia para o Ensino Fundamental I, fiquei sabendo que os alunos do $5^{\circ}$ ano estavam aprendendo o conteúdo referente a população, faixa etária, crescimento vegetativo, IDH e etc. Portanto, a pedido dela, ficou decidido que seria realizado uma aula sobre a população de Uberlândia.

Montei, portanto, um plano de aula para mostrar para a professora, seguindo os conselhos dado pela supervisora do estágio. Conforme o documento, o objetivo principal era demonstrar o crescimento populacional da cidade, 


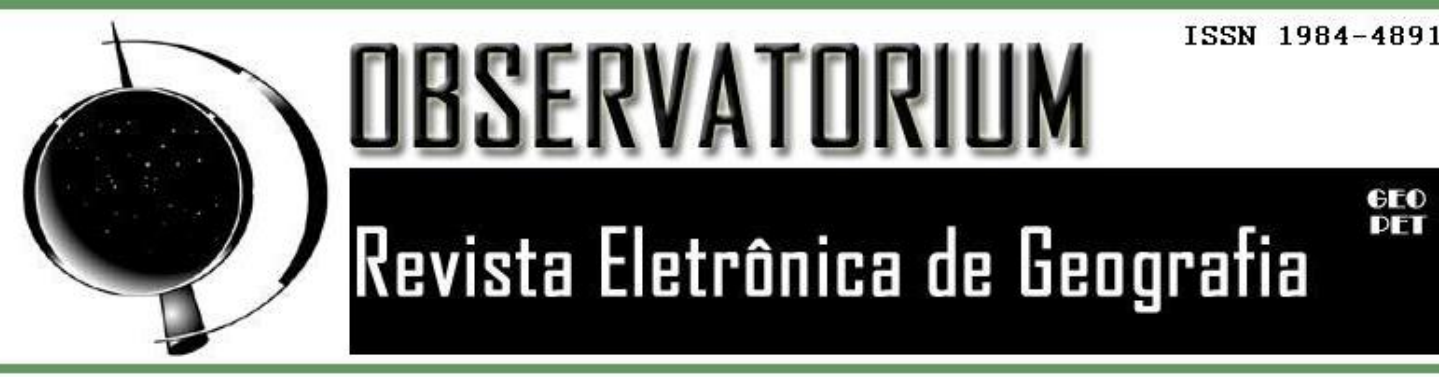

considerando o materialismo histórico do período da década de 1960-1980, através dos fluxos migratórios que ocorreram nessa época. Montei também um documento de rascunho, já que, infelizmente, a escola não possui recursos audiovisuais, tornando um pouco complicado a apresentação de recursos como gráficos e tabelas que apresentam a principal origem dos migrantes que vieram para o município, a questão do crescimento vegetativo, êxodo rural e faixa etária da população uberlandense.

A aula foi ministrada no dia 28 de junho de 2018, no ultimo horário, as 11h10. Ao chegar na sala acompanhando a professora de Geografia, os alunos compreendiam muito bem o conteúdo de população, apesar de eles não terem visto o caso de Uberlândia em especifico. Ao perguntar aos alunos quantos haviam nascido em Uberlândia, praticamente todos levantaram a mão, ao perguntar quem os pais haviam nascido no município, menos alunos levantaram a mão, ao perguntar onde os avós deles haviam nascido, apenas dois alunos mantiveram a mão levantada; esse resultado já era esperado.

Em seguida, foi perguntado aos alunos o que eles pensam ser o motivo de uma pessoa sair de sua cidade natal e mudar para outra. Os alunos em si são muito educados, cada um levanta a mão quando quer falar, e ninguém atrapalha ou corta o outro amiguinho quando o mesmo está falando. Em geral a maioria respondeu que as pessoas se mudam por causa do emprego, os alunos em si não se sentiram intimidados pela minha presença, o que os tornaram muito abertos a falarem sobre o assunto, alguns comentaram sobre a profissão dos pais, sendo que alguns eram representantes de empresas e viajavam muito a trabalho.

Foi explicado a questão da centralidade de Uberlândia como polo regional, sendo que muitas pessoas se mudaram para a cidade pela questão da infraestrutura existente, como hospitais, escolas, a presença da universidade, e outras instalações governamentais que facilitavam a vivencia, assim como a questão da construção de Brasília, com sua influência para expansão das rodovias e por Uberlândia estar "no meio do caminho", tornando-se cruzamento de diversas rodovias que se expandem para o centro-oeste e norte do pais.

Por fim, foram apresentados os dados referentes a pirâmide etária, crescimento vegetativo e a estimativa populacional de Uberlândia no ano de 2017, 


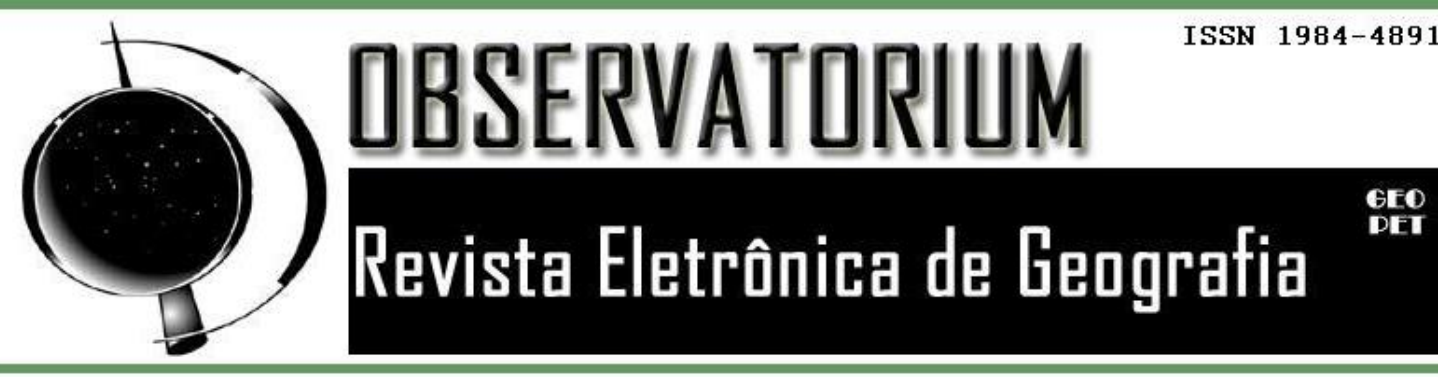

assim como a origem e característica dos migrantes do município. Acredito que os alunos compreenderam o assunto, e espero ter conseguido propiciar conhecimentos novos aos mesmos.

\section{Considerações finais}

Acredito que o estágio seja uma ótima oportunidade para que o aluno entre em contato com a escola de uma forma mais profissional e com uma bagagem de conhecimento que nos permita a análise do espaço e das interações dos alunos.

Portanto, vale indicar que, através das discussões feitas em sala de aula e ajudam a compreender melhor o desenvolvimento do aluno até sua formação plena como cidadão, além de, o estágio servir para mostrar a indissociabilidade entre as etapas da educação. 